\title{
Effect of ECJ Decisions on Budgets of EU Member States: EC Law Without Mercy?
}

\author{
Otmar Thömmes Deloitte \& Touche GmbH, Munich
}

The founders of the European Union and their predecessors who drafted earlier European treaties would have found the number and compass of direct taxation cases coming before the European Court of Justice (ECJ) almost inconceivable. The ECJ has now handed down more than 70 decisions specifically addressing direct taxation issues, and the number of pending cases continues to rise.

While the vast majority of the cases only have marginal implications for the budgets of Member States, some recent cases submitted to the Court may have devastating consequences. Examples of such cases include Marks \& Spencer ${ }^{1}$ (see opinion of Advocate General Poiares-Maduro of 7 April 2005²), involving the ability to offset cross-border losses incurred by EU subsidiaries, Manninen, involving the ability to claim cross-border imputation tax credits $^{3}$ and Meilicke, ${ }^{4}$ a case recently heard by the ECJ involving the old German imputation tax credit system.

The Meilicke case concerns a German resident taxpayer who claimed entitlement to imputation tax credits for corporation tax paid by corporations resident in Denmark and the Netherlands. The taxpayer is the heir of a German shareholder who received dividend income from the corporations in the years 1995-1997. During the years at issue, Germany applied a full imputation tax credit system but the tax credit was restricted to taxes paid by German companies. ${ }^{5}$ The taxpayer's claim was based on the free movement of capital principle in the EC Treaty and the ECJ's decision in the Verkooijen case. ${ }^{6}$ The Court held in Verkooijen that the free movement of capital precludes a Member State from restricting an exemption from income tax on dividends paid to individuals resident in that Member State to dividends paid by a company whose seat is in that same Member
State.

In its 2004 decision in Manninen, the ECJ held that the Finnish imputation tax credit regime - which operated in the same way as the German system in that credits were available only in respect of dividends distributed by resident companies - was inconsistent with the free movement of capital principles in the EC Treaty. The ECJ held that imputation tax credits must be available for dividends received from corporations resident in other EU Member States.

In the Meilicke case, which parallels Manninen, the German Fiscal Court of Muenster requested a preliminary ruling as to whether the EC Treaty requires Germany to extend its imputation tax credit that was in effect from 1977 through 2002 to dividends received by a German resident income taxpayer from a company that is resident in another EU Member State.

The personal freedoms provided for in the EC Treaties on which the taxpayer's claim is based were applicable in the context of the German imputation system from 1977 in the case of shareholders with a qualifying shareholding of $25 \%$ or more, and from 1 July 1990, in the case of portfolio shareholders. ${ }^{7}$ Should the ECJ find for the taxpayer in Meilicke and allow retroactive claims, this could have severe consequences for the German federal budget (with claims for past tax periods going back as far as 1977 or 1990, depending on the case).

In an attempt to restrict the budgetary implications of an ECJ decision in favour of the taxpayer, the German government, at the oral hearing on Meilicke, requested that the ECJ decision either have prospective effect, or alternatively, have effect for fiscal years after 2000, the year Verkooijen was decided.

This attempt by the German government to restrict the fiscal implications of the ECJ decision, which is

\section{Notes}

C-446/03, Marks \& Spencer, OJ C 304 of 13 December 2003, p. 18.

Can be accessed online at curia.eu.int.

Decision of 7 September 2004, C-319/02, Manninen, ECR 2004, p. I-7477.

C-292/04, W. Meilicke and others, a preliminary ruling request submitted by the Tax Court of Cologne, OJ C 228 of 11 September 2004 , p. 27 , EFG 2004, 1374.

Germany abolished its imputation system in 2000.

Decision of 6 June 2000, C-35/98, B.G.M. Verkoijen, ECR 2000, p. I-4073.

Directive 88/361/EEC of 24 June 1988, OJ L 178 of 8 July 1988, p. 5. 
expected to follow the rationale of the Manninen case and which likely will confirm the entitlement of German resident income taxpayers to claim corresponding imputation tax credits for foreign dividends they receive from companies in other EU Member States, has been harshly criticized. It is unlikely that the Court will restrict the implications of its decision.

Will the ECJ simply ignore the fiscal concerns of the Member States and apply EC Law without mercy? When making its decision, the ECJ will likely take the following into account:

- The direct application of the personal freedoms in the EC Treaty to matters of direct taxation: EU Member States have an unconditional obligation to bring their national legislation in line with the mandate of EC law.

- The fact that imputation systems of various Member States discriminated against companies in other EU Member States was well known even before the Manninen and Verkoojen decisions were issued. For example, in 1993, two high-ranking officials in the German tax administration (see Zeitler/Krebs, Der Betrieb 1993, at 1051) published an article in which they commented on pending corporation tax legislation that would have granted a tax credit amounting to $3 / 7$ of dividends received by a German resident income taxpayer regardless of whether the dividend was paid by a domestic company or a company from another EU Member State. The article specifically referred to the new 'EC-compatible taxation of dividends.' In the course of the parliamentary hearings, however, the broadly applicable tax credit was deleted from the draft bill and hence, the imputation credit continued to apply only in the context of domesticsource dividends. After this failed attempt of the German legislature, can anyone claim to be surprised if in 2005 the ECJ requires dividends from companies in other EU Member States to be brought within the scope of Member States' imputation systems?

- The legislatures of the Member States historically have been reluctant to proactively apply ECJ decisions that interpret the EC Treaty, instead preferring to await a decision that specifically addresses the compatibility of their own national law with EC law. To allow Member States to continue to collect revenue from non-EU compatible legislation until such a decision was handed down would create an incentive for noncompliant behaviour. This 'wait and see' attitude would be validated if the ECJ were to place past tax periods outside the reach of its decision.

- A special derogation for Germany in the Meilicke case would be inequitable, particularly in respect of other Member States which, to the detriment of their own tax revenue collection, already have amended their tax legislation and either extended imputation tax credits to EU-source dividends or replaced them with other EU-compatible forms of shareholder relief.

- In the particular case of Finland, the ECJ did not restrict the effects of its decision in Manninen to future periods so why should the Court now do so on the same issue but relative to another Member State?

- Germany passed new legislation only a few weeks after the Manninen decision was issued that specifically limits the potential refunds Germany would have to pay for imputation credit claims (should the ECJ decide in favour of the taxpayer). This legislation sheds additional light on the German tax authorities' general attitude to the 'effet utile' principle under EC law, according to which an EU citizen - or company that invokes fundamental rights under the EC Treaty freedoms must not be impeded or restricted in the exercise of these rights. 